\title{
STUDY REGARDING THE PHYSICAL TRAINING IN FIREFIGHTERS’ OBSTACLE COURSE
}

\author{
Marcel POMOHACI \\ “Lucian Blaga” University, Sibiu, Romania \\ marcelpomohaci@yahoo.com \\ Ioan Sabin SOPA \\ "Lucian Blaga” University, Sibiu, Romania \\ sopa_sabin@yahoo.com
}

\begin{abstract}
Firefighting occupation demands physical and psychological training required in emergency situations. The investigation started in March 2018, with a initial test, and finished in September 2018, with a final test, at the Emergency Situation Unit from Sibiu. The sample of the experiment was formed by 10 firefighters that participate in the emergency team of Sibiu at the specific firefighters' competitions, with age between $30 \pm 3.5$ years old with experience in this kind of competitions between 2 and 7 years. The methods used in our investigation was preponderant experimental with specific testing for firefighters, the data obtained was analyzed using statistical specificity test. The result of our experiment highlighted the progress that every firefighter had, registering a progress of 2.12 second from the initial test 23.48 to the final test 21.36, being statistically significant difference calculated with the $t$ Student test $p=0.00006$. The conclusions of our research showed that using a specific program for developing motor qualities and kinematic analyze, we can improve firefighter's performance and also reduce time of emergency interventions.
\end{abstract}

KEYWORDS: obstacles course, firefighter fitness, developing motor qualities, building

\section{Introduction}

Firefighters workplace represent an unsafe and complex surrounding, that facilitates the risk for accidents and fatalities (Hollerbach et al., 2019). Also adjacent to the unsafe nature of the workplace, firefighters suffer from health problems and reduced physical training, having a critical (over $80 \%$ ) level of overweight and obesity (BMI over 25), supposable that is associated to the fire department employees (Poston et al., 2011).

Insufficient physical and technical training could decrease the firefighter's performance and grow the risk of overworking accidents in firefighters' interventions (Dennison et al., 2012). Also, high level of physical training is connected to reduced degrees of accidents/sickness, low level of absence, increased output, and high level of labor capacity for firefighters (Abel et al., 2011). Firefighter confront extreme temperature and raised heat flux in interventions mostly when they have to intervene in extinguishing fire at structures (Barr et al., 2010; Eglin, 2007) causing high body temperatures (Cheung et al., 2010; McLellan \& Cheung, 2020) and tiredness (Walker et al., 2014). 
Also, firefighters work might imply several tasks in one intervention, and is essential that the regeneration and rest periods to be taken, well-known like firefighters' restoration, that is taken to lower the apparition of soreness and negative health effects (National Fire Protection Association, 2007).

In their work ethic is advised to train and exercise whilst they are at work or pause. Recent investigation proved that firefighters that practice rhythmic trainings have more chances to avoid critical accidents at fire interventions (Jahnke et al., 2013, Poplin, et al., 2016). Moreover, firefighters that have a rhythmic training program and also have better fitness levels are more likely to perform better at jobspecific objectives more productive compared with firefighters that don't train, highlighting the significance of implementing an intense physical training program for firefighters (Dennison et al., 2012; Poplin et al., 2012; Michaelides et al., 2011).

Other scientific research highlighted the importance of growing the muscular strength being an essential virtue in any firefighter's intervention performance (Rhea, 2004), also other papers emphasize the role of cardiovascular training as a problem that also concern the physical training of every firefighter.

Raised physical requirements for firefighter work are multiple and well investigated, firefighters are frequently requested to do their work at or near full capacity under vicious conditions with raised external temperatures and a baggage of objects that are weighing approximatively $35 \mathrm{~kg}$. Also, they are exposed to chemical products and physical soreness that increase the chance for apparition of injuries to the musculoskeletal system, and implies raised metabolic requirements and high levels of sympathetic drive. This vicious framework can produce high level of stress on firefighters' body (Tierney et al., 2010).

This firefighter's occupation has strict and bodily requirements that imply raising and transporting weighty objects, flexure, twisting, in different positions all those pressured by intervention time that has to be fast and prompt (Austin et al., 2001; Baker et al., 2000).

Therefore, in this extreme conditions' firefighters must take fast decisions in close related life-threatening situations, many of them that imply saving of rescuing people or animals or fighting to save buildings or object. Besides fighting fire, other important tasks of firefighters involve resolving medical emergencies, interventions at car crushes or collision, industrial accidents and also keeping and storing equipment in the fire department (Selkirk \& McLellan, 2004).

\section{Objectives of the Research}

The research had as main objective to build a special design program for physical development of firefighters and improve the performance of those emergency employees. As secondary objectives were to improve time in the firefighters' event with obstacles.

\section{Research Method}

The firefighter event " 100 -meter run with obstacles". The contest is attended by eight competitors from the lot, each entitled to two attempts. The competitors are presented at the start line equipped with sport equipment, helmets, belts, sports shoes and they have at belt a " $C$ " type pipe (it can also use block start).

The event is conducted on two - four parallel running corridors. On each of them, the devices are located, according to the diagram in Figure no. 1. 


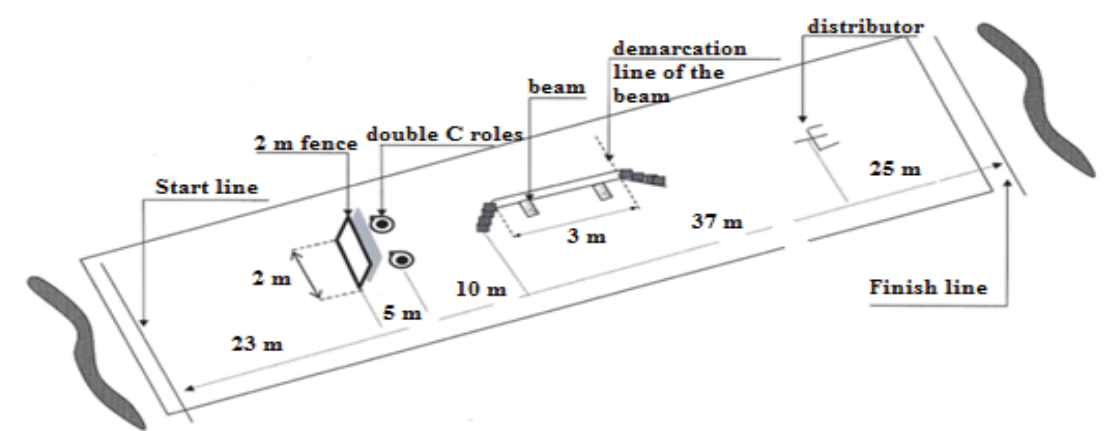

Figure no 1: The obstacle course

(Source: Ministry of Internal Affairs, 2015)

At the "START!" signal, the competitor runs 23 meters, climbs the 2-meter fence, lifts two "C" type hose rollers with which he runs towards the balance beam and crosses it. From the beam or before beginning the descent from it, extend the rollers, connect them together, drop the couplings together and continue running, having in each hand a connection, of which one connects to the distributor and the other connects to the pipe. The event is considered to be completed after the competitor has crossed the finish line with the pipe connected to the hose line.

In order to be able to run with hands free the athletes can have, attached to the belt, a cord, not longer than 50 centimeters, with a carabineer for catching the pipe.

\section{Research Protocol}

\subsection{Research Hypothesis}

The hypothesis of our investigation followed the idea that designing a special program for physical development of firefighters' can improve the performance of emergency employees in the event of the obstacles run.

\subsection{Period and Location of the Research}

Our research took place at the Inspectorate for Emergency Situations from Sibiu, between March 2018 and September 2018. The experiment was carried out on four stages: first stage was the internal contest on departments, second stage was on county, third stage was on region, and the final contest on country.

\subsection{Subjects of the Research}

The subjects of the investigation were 10 males with age between 27-33 years old $(30.2 \pm 3.5$ years old), components of the Emergency Situations from Sibiu with experience in specific firefighters of 2 to 7 years old.

\subsection{The Training Program Designed to Develop Motor Qualities for Training the Firefighters}

Firefighter occupation request many physical and psychological preparation regarding both physical strength, speed, coordination and resistance, and psychological resistance, rapid decision, no fear or anxiety. So, we considered that in order to progress and improve time of intervention we must develop a special training program for motor qualities development, improving time by repeating the obstacle event. Finding and interpreting kinematic parameters by registering the run in the obstacle event we were able to correct the technique of passing the obstacles and improve time of intervention.

In this process of training we were helped by the coach of the Emergency Intervention team from Sibiu, we agreed on specific motor program and a set of athletic exercises that must be carried out that correspond to the needs of firefighter for passing the running with obstacle event. 
Table no. 1

The training program build for developing firefighter skill

\begin{tabular}{|c|c|c|c|c|c|}
\hline \multirow{3}{*}{ No. } & \multirow{3}{*}{ Training program for firefighter } & \multicolumn{4}{|c|}{ The training micro cycles } \\
\hline & & \multicolumn{2}{|c|}{ Micro-cycle (one week) } & \multicolumn{2}{|c|}{$\begin{array}{c}\text { Micro-cycle before } \\
\text { the competition }\end{array}$} \\
\hline & & $\begin{array}{c}\text { Percentage } \\
\text { of the training }\end{array}$ & $\begin{array}{c}\text { Period } \\
\text { allocated }\end{array}$ & $\begin{array}{c}\text { Percentage } \\
\text { of the training }\end{array}$ & $\begin{array}{l}\text { Period } \\
\text { allocated }\end{array}$ \\
\hline 1 & $\begin{array}{l}\text { Athletics exercises (running, } \\
\text { jumping, sprinting, resistance } \\
\text { running, agility, coordination) }\end{array}$ & $30 \%$ & $108 \mathrm{~min}$ & $30 \%$ & $108 \mathrm{~min}$ \\
\hline 2 & $\begin{array}{l}\text { Program for developing strength, } \\
\text { speed, resistance and coordination }\end{array}$ & $20 \%$ & $72 \mathrm{~min}$ & $10 \%$ & $36 \mathrm{~min}$ \\
\hline 3 & $\begin{array}{l}\text { Repeating the event running } \\
\text { with obstacle - on stages } \\
\text { (every obstacle at a time) }\end{array}$ & $20 \%$ & $72 \mathrm{~min}$ & $10 \%$ & $36 \mathrm{~min}$ \\
\hline 4 & $\begin{array}{l}\text { Repeating the entire } \\
\text { race with obstacles }\end{array}$ & $30 \%$ & $108 \mathrm{~min}$ & $50 \%$ & $180 \mathrm{~min}$ \\
\hline
\end{tabular}

Note: The firefighters trained six hours a day, every training had approximatively 360 minutes.

The result of the investigation developed a technical training program model that was named micro cycle of the training that is formed by the micro cycle for developing motor qualities and the pre-competition training program that is programed before the specific competitions of the firefighters the time that is attributed to the correct execution of technique of the firefighter event, from a biomechanical point of view, was inspired from the models of the specialized literature (Neamț et al., 2008; Rate, 2006).

The time attributed to the micro cycle it is possible to be longer while it is allocated, it is possible to train specific technique of running, jumping and climbing borrowed from athletic events (108 minutes), programs to develop strength, resistance and coordination (72 minutes) and other specific training that simulate on stages the specific event (72 minutes), for an average time of 252 minutes and a total of 360 minutes of daily training (adding the repeating the entire race with obstacle).

\section{Execution on segments or assembled performance of the " $100 \mathrm{~m}$ obstacle course”}

a. Training technique of the course and the demonstration of the event, together with explanations.

b. Decomposed execution of the event.

c. The joint execution of the event.

d. Training on execution of the event:

- Climbing the fence of $2 \mathrm{~m}$ (4 exercises).

- Passing over the balance beam (4 exercises).

- Running 50-100 m, carrying two "C" type hose rollers, with belt pipe ( 2 exercises).

- Run 50-100 m, carrying two "B" type hose rollers, with belt pipe (2 exercises).

- Extension of 2 " $C$ " type hose lines and their connection to the distributor (3 exercises).

- Run $5 \mathrm{~m}$, lifting from the ground two "C" type hose rollers, their extension, connection between them, one end to the distributor and the other to the pipe from 
the belt, running to the finish line drawn at $50 \mathrm{~m}$ (2 exercises).

- Run $5 \mathrm{~m}$, lifting a B-CBC distributor and a "C" type hose roller from the ground, $30 \mathrm{~m}$ running continued, placing the distributor on the ground, stretching the hose roller, connecting one end to the distributor and the other to the pipe from the belt, running to the finish line drawn at $50 \mathrm{~m}$ (3 exercises).

- Running $23 \mathrm{~m}$, climbing the fence of $2 \mathrm{~m}$, continuing the running $5 \mathrm{~m}$ and lifting two "C" type hose roller (2 exercises).

- Running $23 \mathrm{~m}$, climbing the fence of $2 \mathrm{~m}$, running $5 \mathrm{~m}$ and lifting two $\mathrm{C}$ rollers, stretching and connecting them (2 exercises).

- Running $5 \mathrm{~m}$, lifting two "C" type hose rollers, $10 \mathrm{~m}$ running, crossing the balance beam with the hose rollers stretched (3 exercises).

- Running $23 \mathrm{~m}$, climbing the fence of $2 \mathrm{~m}$, running $15 \mathrm{~m}$ and crossing over the balance beam, running $50 \mathrm{~m}$; scale of grades: under 15 seconds.

- Start with belt pipe, running 23 $\mathrm{m}$ and climbing the fence of $2 \mathrm{~m}$ (3 exercises)

- Running $5 \mathrm{~m}$ and lifting two " $\mathrm{C}$ " type hose rollers, their extension and connection between them ( 5 exercises).

- Running $45 \mathrm{~m}$, with two "C" type hose rollers, their extension, connection between them and the distributor (3 exercises).

- Running with two connected hose rollers, connecting one end to the distributor, and the other to the belt pipe ( 2 exercises).

- Training in the joint execution of the test "100 m with obstacles" - in accordance with the standardized scales provided.

The next step in the present research, after the content of the experiment, is the analysis of the results obtained after the practical control tests.

For this purpose, the tables and graphs on the following pages, tables containing times completed and notes obtained at the practical control tests by each subject, in each initial or final test, were of great help.

For a better analysis of the data obtained, we tried to present, through the graphical method, the times achieved and the notes obtained by the group of subjects at the end of each initial and final evaluation.

\section{Results}

The investigation started with an initial test in April 2018 when we registered the results at the $100 \mathrm{~m}$ run with obstacle. The results were registered and then analyzed. After the initial testing we started the developing program for firefighters and analyzed their performance in every month. For every performance we registered the time and give a grade (values between 24-25 were noted with 7; values between 23-24 were noted with 8 ; values between 22-23 were noted with 9; values between 21-22 were noted with 10).

Table no. 2

The results of the firefighters at every testing

\begin{tabular}{|c|c|c|c|c|c|c|c|c|c|c|c|}
\hline Event & \multicolumn{11}{|c|}{ "100 m with obstacle run" } \\
\hline \multirow{3}{*}{ Subject } & \multirow{3}{*}{ Age } & \multicolumn{10}{|c|}{ Evaluation performed (1 initial test, 3 intermediate tests, 1 final test) } \\
\hline & & \multicolumn{2}{|c|}{$\begin{array}{c}\text { April } \\
\text { (initial test) }\end{array}$} & \multicolumn{2}{|c|}{$\begin{array}{c}\text { May } \\
\text { (intermediate } \\
\text { test) }\end{array}$} & \multicolumn{2}{|c|}{$\begin{array}{c}\text { June } \\
\text { (intermediate } \\
\text { test) }\end{array}$} & \multicolumn{2}{|c|}{$\begin{array}{c}\text { July } \\
\text { (intermediate } \\
\text { test) }\end{array}$} & \multicolumn{2}{|c|}{$\begin{array}{l}\text { September } \\
\text { (Final test) }\end{array}$} \\
\hline & & $\begin{array}{l}\text { Perf } \\
(\mathrm{sec})\end{array}$ & Grade & $\begin{array}{l}\text { Perf } \\
(\mathrm{sec})\end{array}$ & Grade & $\begin{array}{l}\text { Perf } \\
(\mathrm{sec})\end{array}$ & Grade & $\begin{array}{l}\text { Perf } \\
(\mathrm{sec})\end{array}$ & Grade & $\begin{array}{l}\text { Perf } \\
(\mathrm{sec})\end{array}$ & Grade \\
\hline Sub 1 & 30 & 24.2 & 8 & 22.6 & 9 & 24.1 & 8 & 23.5 & 9 & 22.2 & 10 \\
\hline Sub 2 & 29 & 22.8 & 9 & 22.4 & 9 & 23.2 & 8 & 22.6 & 9 & 21.5 & 10 \\
\hline
\end{tabular}




\begin{tabular}{|c|c|c|c|c|c|c|c|c|c|c|c|}
\hline Event & \multirow{2}{*}{\multicolumn{11}{|c|}{$\begin{array}{c}\text { "100 m with obstacle run" } \\
\text { Evaluation performed ( } 1 \text { initial test, } 3 \text { intermediate tests, } 1 \text { final test })\end{array}$}} \\
\hline \multirow{3}{*}{ Subject } & & & & & & & & & & & \\
\hline & \multirow[t]{2}{*}{ Age } & \multicolumn{2}{|c|}{$\begin{array}{c}\text { April } \\
\text { (initial test) }\end{array}$} & \multicolumn{2}{|c|}{$\begin{array}{c}\text { May } \\
\text { (intermediate } \\
\text { test) }\end{array}$} & \multicolumn{2}{|c|}{$\begin{array}{c}\text { June } \\
\text { (intermediate } \\
\text { test) }\end{array}$} & \multicolumn{2}{|c|}{$\begin{array}{c}\text { July } \\
\text { (intermediate } \\
\text { test) }\end{array}$} & \multicolumn{2}{|c|}{$\begin{array}{l}\text { September } \\
\text { (Final test) }\end{array}$} \\
\hline & & $\begin{array}{l}\text { Perf } \\
(\mathrm{sec})\end{array}$ & Grade & $\begin{array}{l}\text { Perf } \\
(\mathrm{sec})\end{array}$ & Grade & $\begin{array}{l}\text { Perf } \\
(\mathrm{sec})\end{array}$ & Grade & $\begin{array}{l}\text { Perf } \\
(\mathrm{sec})\end{array}$ & Grade & $\begin{array}{l}\text { Perf } \\
(\mathrm{sec})\end{array}$ & Grade \\
\hline Sub 3 & 26 & 22 & 9 & 22.5 & 9 & 21.3 & 10 & 18.4 & 10 & 17.5 & 10 \\
\hline Sub 4 & 31 & 23.5 & 8 & 22.8 & 9 & 23.5 & 8 & 21 & 10 & 19.5 & 10 \\
\hline Sub 5 & 27 & 24.4 & 7 & 24 & 8 & 24.2 & 7 & 24.4 & 7 & 23.7 & 8 \\
\hline Sub 6 & 30 & 23 & 9 & 22.5 & 9 & 21.5 & 10 & 22.2 & 9 & 21.8 & 10 \\
\hline Sub 7 & 32 & 24.4 & 7 & 24 & 8 & 23.7 & 8 & 23.5 & 8 & 23 & 9 \\
\hline Sub 8 & 28 & 24 & 8 & 23.5 & 8 & 24.1 & 8 & 23.7 & 8 & 22.5 & 9 \\
\hline Sub 9 & 30 & 24 & 8 & 24.4 & 7 & 23.8 & 8 & 22.7 & 9 & 22.5 & 9 \\
\hline Sub 10 & 29 & 22.5 & 9 & 22.8 & 9 & 23.3 & 8 & 20.2 & 10 & 19.4 & 10 \\
\hline Average & 29.2 & 23.48 & 8.2 & 23.15 & 8.5 & 23.27 & 8.3 & 22.22 & 8.9 & 21.36 & 9.5 \\
\hline
\end{tabular}

Legend: Values between 24-25 were noted with 7; values between 23-24 were noted with 8; values between 22-23 were noted with 9; values between 21-22 were noted with 10

\section{Statistical interpretation of the data}

The $\mathbf{P}$ value and statistical significance:

The two-tailed $P$ value equals 0.0006

By conventional criteria, this difference is considered to be extremely statistically significant.

Confidence interval:

The mean of Group One minus Group Two equals 2.120

$95 \%$ confidence interval of this difference: From 1.197 to 3.043
Intermediate values used in calculations:

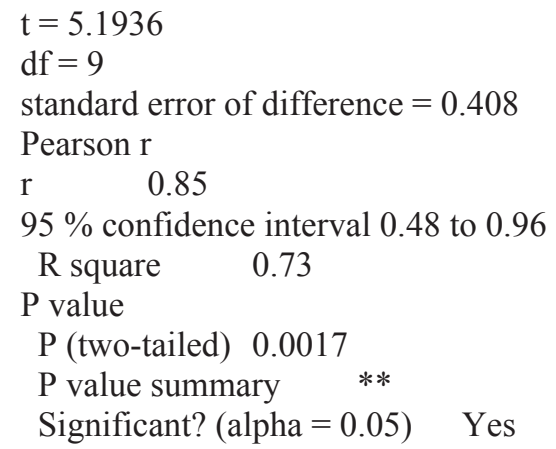

Table no. 3

Statistics between initial test and final test

\begin{tabular}{|l|c|c|}
\hline \multicolumn{1}{|c|}{ Group } & Group One & Group Two \\
\hline Mean & 23.480 & 21.360 \\
\hline SD & 0.856 & 1.940 \\
\hline SEM & 0.271 & 0.614 \\
\hline N & 10 & 10 \\
\hline Conf. interval of difference from 1.197 to 3.043 \\
\hline P-value $=0.0006-$ extremely statistically significant \\
\hline
\end{tabular}




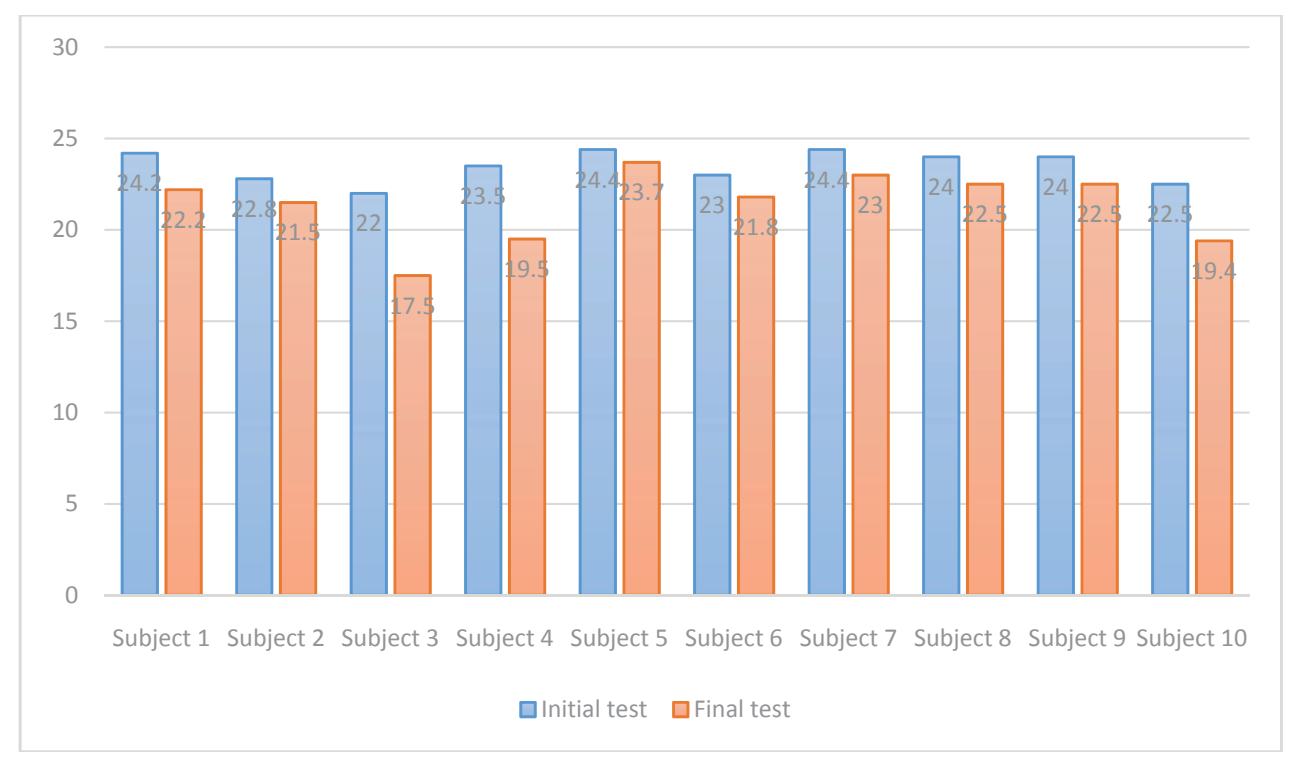

Figure no. 2: Difference between initial test and final test for every sportive

\section{Discussions}

During simulation of reality firefighter interventions in related conditions, some researches tried to measure some specific characteristics like the level of oxygen uptake, heart rate, and blood lactate concentrations (Perroni et al., 2009; Perroni et al., 2010) and acknowledge that firefighting job is on the first places as one of the most exhausting and unpredictable of all civilian working jobs that have the main objective to save or secure beings and humans. Also other scientific research highlighted the importance of psychomotor skills in the training of military staff (Khmiliar \& Klymenko, 2020) that is also important in firefighters physical preparation.

The results of our investigation confirmed that intervention time of the firefighters in emergency situation can be improved by training with specific methods, developing motor qualities, physical strength and also repeating emergencies scenarios that are provided in the $100 \mathrm{~m}$ run with obstacles.
High performances are obtained by training with multidisciplinary methods borrowed from athletics domain or by kinematic analyze of the executions and repairing the mistakes of execution.

Results of the research proved that using a high intensity specific training, firefighters can improve their time of intervention and also time obtained at the $100 \mathrm{~m}$ run with obstacles event. The average of intervention time at the initial testing of our firefighter team was 23.48 , and improved by every month at the intermediate testing until the final testing in September 2018 where our squad obtained a record unit time of 21.36 seconds, being close to the national record and also to the international record.

Some research highlighted the idea that physiological stress is one of the main reasons that contribute to the combined effect of the metabolically active muscles that are used for heavy muscular work (Bilzon, 2001) and also for the thermo adjustment system (McLellan \& Selkirk, 2004; Smith et al., 2001; Smith et al., 2005) arising from the heavy (approximatively $23 \mathrm{~kg}$ ), insulation, 
non-permeable protection equipment (specific gloves, firefighter boots, Nomex flash hood, helmet) and a independent breathing device, for additional weight (pumps that are connected to the water hydrants, using raised-pressure hoses, firefighter specific ladders, pick up weights, saving causalities, offering emergency medical care, and airing the smoke-filled places) (Perroni, et al., 2014). Furthermore, an extent intervention period (over 10 weeks) possible to be an advantage compared with 16-week interventions period (Abel et al., 2011; Roberts et al., 2002). In any case, raising the level of fitness at firefighters' personnel can be seen after just eight weeks of workout with circuit exercise training (Heinrich et al., 2012).

\section{Conclusions}

The firefighter's occupation is a very physical demanding job that needs good physical and psychological development.

The conclusions of our investigation proved that firefighters need special programs for developing motor qualities, physical improvements and athletic exercises for preparing their emergency abilities. Our investigation results highlighted the improvement of intervention time of the Emergency Situation Unit from Sibiu, from a initial average team result of 23.48 second to the final test with a value of 21.36. The improvement time is a very good result bringing the ESU Sibiu very close to the national team record for $100 \mathrm{~m}$ run with obstacles.

\section{REFERENCES}

Abel, M. G., Mortara, A. J., \& Pettitt, R. W. (2011). Evaluation of circuit-training intensity for firefighters. Journal of Strength and Conditioning Research, Vol. 25, Issue 10, 2895-2901. DOI: 10.1519/JSC.0b013e31820da00c.

Austin, C. C., Dussault, G., Ecobichon, D. J. (2001). Municipal firefighter exposure groups, time spent at fires and use of self-contained-breathing-apparatus. American Journal of Industrial Medicine, Vol. 40, Issue 6, 683-692. https://doi.org/10.1002/ajim.10023

Barr, D., Gregson, W., Reilly, T. (2010). The thermal ergonomics of firefighting reviewed. Journal of Applied Ergonomics, Vol. 41, Issue 1, 161-72. DOI: 10.1016/j.apergo.2009.07.001.

Bilzon, L. J., Scarpello, E. G., Smith, C. V., Ravenhill, N. A., Rayson, M. (2001). Characterization of the metabolic demands of simulated shipboard Royal Navy firefighting tasks. Journal of Applied Ergonomics, Vol. 44, 766-780. https://doi.org/10.1080/ 00140130118253.

Cheung, S., Petersen, S., McLellan, T. (2010). Physiological strain and countermeasures with firefighting. Scandinavian Journal of Medicine Science of Sports, Vol. 20, Issue 3, 103-16. https://doi.org/10.1111/j.1600-0838.2010.01215.x

Dennison, K. J., Mullineaux, D. R., Yates, J. W., \& Abel, M. G. (2012). The effect of fatigue and training status on firefighter performance. Journal of Strength Conditioning Research, Vol. 1101. DOI: 10.1519/JSC.0b013e31822dd027.

Eglin, C. M. (2007). Physiological responses to fire-fighting: thermal and metabolic considerations. Journal of the History of Environment and Society, Vol. 10, Issue 1, 7-18. DOI: $10.1007 / \mathrm{s} 00421-005-0015-6$.

Hollerbach, B. S., Jahnke, S. A., \& Poston, W. S. C. (2019). Examining a novel firefighter exercise training program on simulated fire ground test performance, cardiorespiratory endurance, and strength: a pilot investigation. Journal of Occupational Medicine Toxicology, Vol. 14, 12. https://doi.org/10.1186/s12995-019-0232-2. 
Jahnke, S. A., Poston, W. S. C., Haddock, C. K., \& Jitnarin, N. (2013). Injury among a population-based sample of career firefighters in the Central USA. Journal of Injury prevention, Vol. 19, Issue 6, 393-8.DOI:10.1002/oby.20436

McLellan, T. M., \& Selkirk, G. A. (2004). Heat stress while wearing long pants or shorts under firefighting protective clothing. Journal of Applied Ergonomics, Vol. 47, 75-90.

https://doi.org/10.1080/00140130310001611125

McLellan, T. M., \& Cheung, S. S. (2020). Impact of fluid replacement on heat storage while wearing protective clothing. Journal of Applied Ergonomics, Vol. 43, Issue 12, 30. DOI: $10.1080 / 00140130050201454$

Michaelides, M. A., Parpa, K. M., Henry, L. J., Thompson, G. B., \& Brown, B. S. (2011). Assessment of physical fitness aspects and their relationship to firefighters' job abilities. Journal of Strength and Conditioning Research, Vol. 25, Issue 4, 956-965. DOI: $10.1519 /$ JSC.0b013e3181cc23ea

Ministry of Internal Affairs. (2015). Ordinul Inspectorului General al Inspectoratului General pentru Situaţii de Urgenţă. Nr. 153-IG din 19.02.2015 privind organizarea şi desfăşurarea pregătirii personalului operativ din subunităţile de intervenţie ale serviciilor de urgenţă profesioniste - ISU 06/2015, p. 214.

National Fire Protection Association (NFPA) 1584. (2007). Standard on the Rehabilitation Process for Members during Emergency Operations and Training Exercises. Quincy, MA: National Fire Protection Association.

Khmiliar, O., \& Klymenko, V. (2020). Cadets' psychomotor development as a prerequisite for their personal readiness to act in conditions of uncertainty. The European Journal of Social and Behavioral Sciences, Vol. XXVIII, 3157-3169. DOI:10.15405/ejsbs.275

Perroni, F., Tessitore, A., Cibelli, G., Lupo, C., D’Artibale, E., Cortis, C., Cignitti, L., De Rosas, M., \& Capranica, L. (2009). Effects of simulated firefighting on the responses of salivary cortisol, alpha-amylase and psychological variables. Journal of Applied Ergonomics, Vol. 52, Issue 4, 484-4914. DOI: 10.1080/00140130802707873

Perroni, F., Tessitore, A., Cortis, C., Lupo, C., D’Artibale, E., Cignitti, L., \& Capranica, L. (2010). Energy cost and energy sources during a simulated firefighting activity. Journal of Strength and Conditioning Research, Vol. 24, Issue 12, 3457-3463. DOI:10.1519/ JSC.0b013e3181b2c7ff.

Perroni, F., Cortis, C., Minganti, C., Cignitti, L., \& Capranica, L. (2014). Maximal oxygen uptake of Italian firefighters: Laboratory vs. field evaluation. Sport Sciences for Health, Vol. 9, Issue 2, 31-35. DOI: 10.1007/s11332-013-0142-0

Poplin, G. S., Roe, D. J., Burgess, J. L., Peate, W. F., \& Harris, R. B. (2016). Fire fit: assessing comprehensive fitness and injury risk in the fire service. International Archives of Occupational Environmental Health, Vol. 89, Issue 2, 251-9. DOI:10.1007/s00420-015-1068-4

Poston, W. S., Haddock, C. K., Jahnke, S. A., Jitnarin, N., Tuley, B. C., \& Kales, S. N. (2011). The prevalence of overweight, obesity, and substandard fitness in a population-based firefighter cohort. Journal of Occupational Medicine Toxicology, Vol. 533, 266-73. DOI:10.1097/JOM.0b013e31820af362.

Rhea, M. R., Alvar, B. A., \& Gray, R. (2004). Physical fitness and job performance of firefighters. Journal of Strength and Conditioning Research, Vol. 18, Issue 2, 348-352. DOI:10.1519/R-12812.1

Roberts, M. A., O’Dea, J., Boyce, A., \& Mannix, E. (2002) Fitness levels of firefighter recruits before and after a supervised exercise training program. Journal of Strength and Conditional Research, Vol. 16, Issue 2, 271-7. DOI:10.1519/15334287(2002) $016<0271$ :flofrb $>2.0$. co; 2 
Smith, D. L., Manning, T. S., \& Petruzzello, S. J. (2001). Effect of strenuous live-fire drills on cardiovascular and psychological responses of recruit firefighters. Journal of Applied Ergonomics, Vol. 44, 244-254. DOI: 10.1080/00140130010000910

Smith, D. L., Petruzzello, S. J., Chludzinski, M. A., Reed, J. J., \& Woods, J. A. (2005). Selected hormonal and immunological responses to strenuous live-fire firefighting drills. Journal of Applied Ergonomics, Vol. 48, 55-65. https://doi.org/10.1161/ CIRCULATIONAHA.116.025711

Tierney, M. T., Lenar, D., Stanforth, P. R., Craig, J. N., \& Farrar, R. P. (2010). Prediction of aerobic capacity in firefighters using submaximal treadmill and stair mill protocols. Journal of Strength and Conditioning Research, Vol. 24, Issue 3, 757-764. DOI:10.1519/JSC.0b013e3181c7c282

Walker, A., Driller, M., Brearley, M., Argus, C., \& Rattray, B. (2014). Cold water immersion and iced-slush ingestion are effective at cooling firefighters following a simulated search and rescue task in a hot environment. Journal of Applied Physiology, Nutrition, and Metabolism, Vol. 39, Issue 10, 1159-66. DOI: 10.1139/apnm-2014-0038 